\title{
Landuse change monitoring and population density analysis of Penjaringan, Cengkareng, and Cakung Urban Area in Jakarta Province
}

\author{
Ratih Fitria Putri ${ }^{1, *}$, Sunu Wibirama ${ }^{2}$, Sri Rum Giyarsih ${ }^{1}$, Aditya Pradana ${ }^{1}$, and Yanti Kusmiati ${ }^{1}$ \\ ${ }^{1}$ Department of Environmental Geography, Faculty of Geography, Universitas Gadjah Mada, Indonesia \\ ${ }^{2}$ Department of Electrical Engineering and Information Technology, Faculty of Engineering, Universitas Gadjah Mada, Indonesia
}

\begin{abstract}
Rapid landuse change in an urban area is inevitable. Jakarta as the capital city of Indonesia is experiencing rapid landuse change. Jakarta is the centre of administration, economic activities, and entertainment pull people coming in to Jakarta. The dynamics of demography in Jakarta influences landuse change strongly. This research use three districts in Jakarta to see how landuse change over period of time. They are Penjaringan, Cengkareng, and Cakungsubdistrict. By combining landuse data, demographic features, and spatial data, such as satellite imagery, landuse change can be monitored and explained. The most significant landuse changes are industrial area and settlements. Both landuses are expanding. Meanwhile open spaces are decresing in size. This happens due to high demand of settlements caused by migrants coming in to work in industrial are. The result of this phenomenon is slum area in the city and lack of opened green spaces that can degrade environmental quality.
\end{abstract}

\section{Introduction}

Jakarta as Indonesia's capital has an important function as a home for more than thirteen million inhabitants. Jakarta had a role as the Centre of the economy of the country at the same time the Central Government is causing high incoming migration to Jakarta. The development condition of Jakarta from time to time strongly influenced the dynamics of demographic conditions with an impact that can be identified is the land use change. Subdistrict of Penjaringan, Cengkareng and Cakung is a strategic area in Jakarta with vital functions as an industrial and trading centre inside the region. The issue of population density, land use change, as well as changes in environmental conditions is a determinant factors that influenced the development of the three subdistricts.

Penjaringan is one of the subdistricts which are located in Jakarta Utara. It is located directly adjacent to the Java Sea in the northern part and the southern part of the subdistrict of Cengkareng. Its strategic location makes Penjaringan as peripherals region from Jakarta Pusat, where Jakarta Pusat is core region of DKI Jakarta. Penjaringan as peripheral region experiencing the various dynamics of social good as well as the physical environment. Socially, demographic change in Penjaringan subdistrict given the fluctuating migration in DKI Jakarta, while physically the environment dynamic represented by land use change following the needs of the community. This means that both these changes will influence each other each other. Analysis of the changes of the social and physical environment conditions that will be examined not only Penjaringan but also include Cengkareng and Cakungsubdistrict.

Demographic conditions that exist in these three subdistricts shows that there is a difference, it can be affected by several things including the distance towards the centre, community facilities are available, and the level of fungtional region. When compared with the two other subdistrict, Penjaringan's demographic conditions are relatively stable and not experience increased drastically in the years 2010 to 2015 . Comparison of all three can be seen in Table 1.

Table 1. Number of inhabitatnts (People).

\begin{tabular}{|l|c|c|c|c|}
\hline \multirow{2}{*}{ Subdistrict } & \multicolumn{4}{|c|}{ Year } \\
\cline { 2 - 5 } & $\mathbf{2 0 1 0}$ & $\mathbf{2 0 1 1}$ & $\mathbf{2 0 1 3}$ & $\mathbf{2 0 1 5}$ \\
\hline Cakung & 408901 & 510917 & 480718 & 506158 \\
\hline Cengkareng & 304440 & 466907 & 492330 & 498130 \\
\hline Penjaringan & 306456 & 302952 & 296062 & 332864 \\
\hline
\end{tabular}

Source: DKI Jakarta in Numbers 2016 [1].

Based on Table 1, it can be seen that the number of inhabitants of Penjaringan from 2010 until 2015 has always had the lowest number when compared to the other two districts. However, when seen from the area of the region between all three, it is known that Penjaringan has an area of greater i.e., $45.41 \mathrm{~km}^{2}$, as compared to the total area of the region of Cengkareng, $26.54 \mathrm{~km}^{2}$, and Cakung, $42.47 \mathrm{~km}^{2}$. This led to Penjaringan has the least

* Corresponding author: ratihfitria.putri@ugm.ac.id 
population density among three subdistrict. Population density calculation results can be seen in Table 2 .

Table 2. Population density.

\begin{tabular}{|l|c|c|c|c|}
\hline \multirow{2}{*}{ Subdistrict } & \multicolumn{4}{|c|}{ Year } \\
\cline { 2 - 5 } & $\mathbf{2 0 1 0}$ & $\mathbf{2 0 1 1}$ & $\mathbf{2 0 1 3}$ & $\mathbf{2 0 1 5}$ \\
\hline Cakung & 9628 & 12084.13 & 11319 & 11918 \\
\hline Cengkareng & 11471 & 17592.58 & 18550 & 18769 \\
\hline Penjaringan & 6749 & 6671.482 & 6520 & 7330 \\
\hline
\end{tabular}

Source: Data Calculation 2018.

Based on Table 2, can be note that Penjaringan has a relatively small population density between these three areas of study. The low population density in Penjaringan can occur due to a large area with a relatively small population. The low population can be affected by its location bordering the Java Sea in its northern part. Penjaringan often suffered flooding, whether caused by high rainfall as well as by the existence of the tide (rob). Flood happened in Penjaringan is not only caused by natural factors but also caused by the decrease in the ground because of inappropriate land use so that the burden of land subsidence occurred till. This research is aimed to understand the landuse monitoring and population density analysis in Jakarta urban area.

\section{Methods}

This study is using a descriptive explorative method with descriptive statistic as illustrating the object of study through actual sample or population data. Using this method, this study will describe characteristic of study area according the actual condition, particularly the population density and landuse change. Landuse change mapping was created by overlay method of topography map and aerial photograph. To calculate the population density, it divided the population by the size of the area. Thus, Population Density $=$ Number of People/Land Area.Hence, it can identify and analyze the correlation between landuse change condition and population density analysis.

\section{Results and discussions}

\subsection{Penjaringan subdistrict}

Based on the Spatial Plan of the region of DKI Jakarta in 2010, district of Penjaringan functions as protected areas (with an area of 200,000 ha), North Beach area, trade zone and industrial zone. Land use arrangements intended to protect the land and the public from the threat of disasters that may occur, in addition to undertake sustainable development. Developmentof the territory inaccordance with RTRW can lead to land degradation, as has happened in Penjaringan. The environmental conditions that are less convenient for the home can be the main reason for the low number of inhabitants existing in trawls when compared with other subdistrict. It can also be seen in the decrease in the number of residents of the subdistrict of networking in 2010 to 2013 in Figure 1. Moreover, less industrial centre activities compare than Cengkareng and Cakung, Penjaringan have less population number.

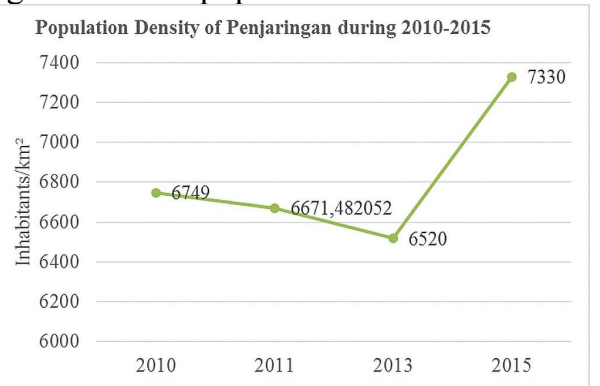

Fig. 1. Population density of Penjaringan. Source: Data Measurement 2018

Population decline in 2010 to 2013 can be caused by the flood that has always plagued this subdistrict, many of the residents chose to move into other areas. An increase in the number of inhabitants in the year 2015 may occur due to the lack of any other options to stay there, considering Jakarta is the field a great job attracting job seekers you met the fate in Jakarta. The increase in population is not only experienced by the Penjaringan Subdistrict alone but also the Cakung and Cengkareng. Subdistrict of Penjaringan is divided into nine types of land use.

Table 3. Penjaringan's land use type

\begin{tabular}{|l|c|c|c|}
\hline \multirow{2}{*}{\multicolumn{1}{c|}{ Landuse }} & \multicolumn{3}{c|}{ Area (ha) } \\
\cline { 2 - 4 } & $\mathbf{2 0 1 1}$ & $\mathbf{2 0 1 3}$ & $\mathbf{2 0 1 6}$ \\
\hline Reservoir & 90.69 & 90.69 & 90.69 \\
\hline Other public facilities & 3.69 & 3.69 & 3.69 \\
\hline City forest & 34.07 & 34.07 & 34.07 \\
\hline Industrial areas & 829.8 & 877.77 & 909.39 \\
\hline Settlement & 1596.5 & 1557.62 & 1552.42 \\
\hline Transportation facilities & 88.84 & 88.84 & 90.73 \\
\hline Open zone & 814.77 & 805.68 & 993.28 \\
\hline River & 91.61 & 91.61 & 91.61 \\
\hline Pond & 313.24 & 313.24 & 296.43 \\
\hline
\end{tabular}

Based on Table 3, Figure 2 and 3, known in 2011, 2013 to 2016 has land use change may occur. In General land use in Penjaringan in the form the settlement covers 38 percent of the total area, then followed by the dam/reservoir covering an area of 25 percent. In third position was the industrial area of roughly 23 percent. Land use change in Penjaringan in 2011 to 2013 is not too significant. Covering an area of settlement land acres 38.87 turned into an industrial area. While land use change from 2013 to 2016 are more significant. Changing land use, occur in industrial area, settlements, 
transport infrastructure, open space and farm land use, while the four others unchanged $[2,3]$.

Industrial area during 2011 to 2016 is experiencing an expansion of as much as 79.59 hectares In 2011 covering an area of 829.80 hectares later in 2016 be 909.39 hectares. While the settlement land area narrowed 44.07 hectares. In 2011 covering an area of 1596.50 hectares later in 2016 be 1552.42 hectares. Narrowing the broad settlement followed a decrease in the number of inhabitants in Penjaringan. This is due to the complexity of the problems that existed in Jakarta Utara, one of them the threat of tidal flood inundation and land deformation $[4,5,6]$

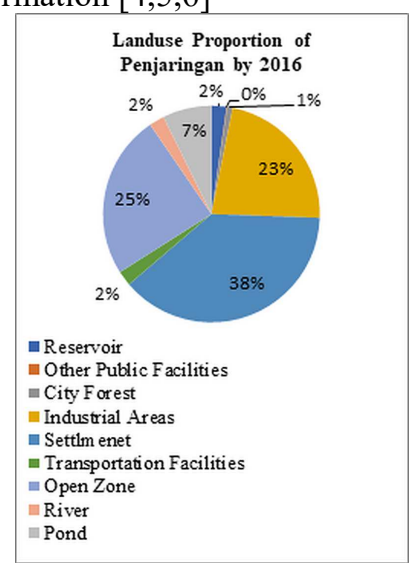

Fig. 2. Landuse presentation in Penjaringan by 2016. Source: Data Processing 2018

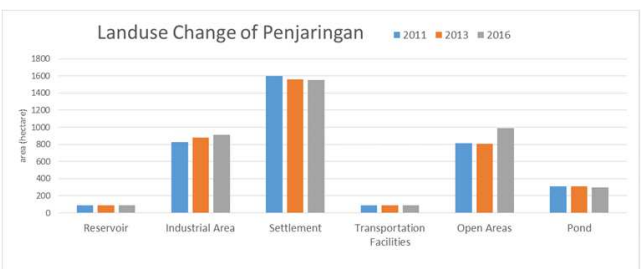

Fig. 3. Landuse change during 2011-2016.

Source: Data Proccesing

Based on the research of Purnama et al. [7] said that areas with danger of flooding is high in eastren part of Penjaringan. The impact of tidal floods with a height of $30 \mathrm{~cm}$ only appears on the North coast of Penjaringan, while at an altitude of $115 \mathrm{~cm}$ and $200 \mathrm{~cm}$ impact appears to be up in nearly the entire Penjaringan. Economic losses which are based economic value of land use shows the height of $200 \mathrm{~cm}$ yield losses 4.7 billion rupiah. Meanwhile, open space in Penjaringan increased significantly from 805.68 hectares in 2013 being 993.28 hectares in 2016. This happens because the presence of beach reclamation.

\subsection{Cengkareng subdistrict}

Cengkareng subdistrict is one of the subdistricts in Jakarta Barat territory with the highest population in Jakarta until reaching 494.7 thousand inhabitants or covers of 4.9 total DKI Jakarta residents in 2015 as in Figure 4. Cengkareng population is very high is inseparable from the function of Cengkareng as a strategic industrial center located near Jakarta International Soekarno-Hatta Airport. Data of BPS Jakarta Barat, 2015 explains that there are 43 large industrial centre and 119 industrial centre are located in Cengkareng until 2013. The high number of industry as the main source of jobs most of the residents in Jakarta, causing many residents choose location resides around the industrial areas.

Subdistrict of Cengkareng has an area $27.93 \mathrm{~km} 2$ divided into 6 wards. As narrow area with high population, it is causes Cengkareng had high levels of population density. Based on the data of the population density in 2010 to 2015 in Figure 6, is known to have an increase in population density significantly from year to year. Population density increased from 11,471 inhabitants $/ \mathrm{km} 2$ in 2011 be 18,769 inhabitants $/ \mathrm{km} 2$ in 2015 (Figure 5). An increasing number of population density occurs due to an increase in the number of population in Cengkareng, which can be caused by an increase in births as well as an increase in the number of incoming migration particularly productive workers in the field of industrial migration mainly from rural areas.

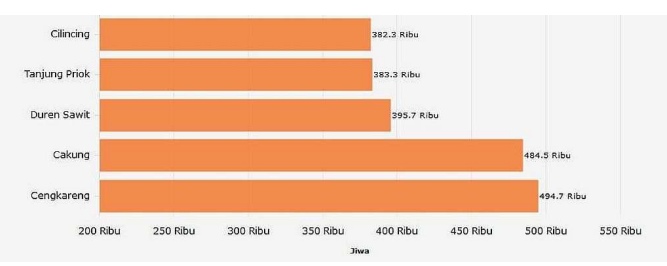

Fig. 4. Five subdistricts in DKI Jakarta with the highest number of population.

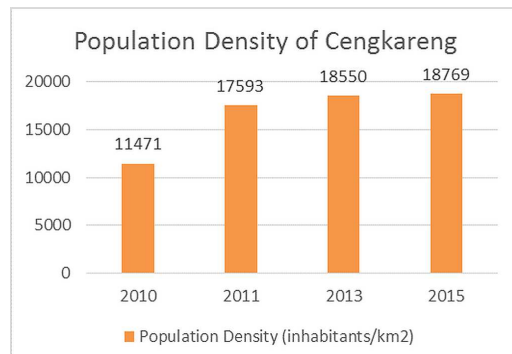

Fig. 5. Population density of Cengkareng. Source: BPS Jakarta Barat, 2016 (Processed) [8].

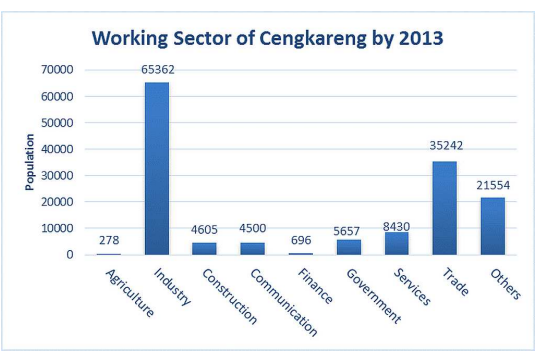

Fig. 6. Distribution of population's working sector in Cengkareng. Source: Data Calculation 2018 


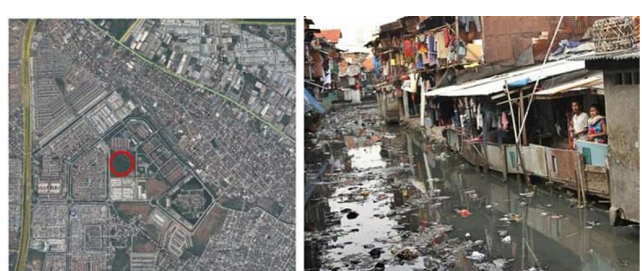

Fig. 7. (A) Slum Areas nearby indutrial zone, (b) slums in Duri Kosambi, Cengkareng

Increase in the number of population density is inseparable from the increasingly high demand jobs in the industrial sector in Cengkareng. This led to the migrants who have obtained employment tend to settle in the area and increase the population density. The data distribution of the work population in Figure 6 tells us that 44 per cent of the population work in the industrial sector. This explains the importance of the industrial areas existence as the main determinant factor defining very high population density in Cengkareng. The population density was causing the land for settlement and industry are increasing. BPS Jakarta Barat 2013, explaining there are at least $27 \mathrm{RW}(32 \%)$ entering the category of slum among $84 \mathrm{RW}$ in total. High population density triggers the growth of slums in the city especially the surrounding industrial areas, as shown in Figure 7.

The progress of development in a region in line with the increase in population has always been accompanied by rising standards of quality and quantity of the necessities of life and improvement availability needs facilities that led to changes in land use. The land use for the area woke up the longer growing caused by rapid development for residential, industrial and office space. Cengkareng is a subdistrict as one of the most populous subdistrict in Jakarta with an area of 2654 ha undergoing significant changes in land use.

Table 4. Landuse type in Cengkareng.

\begin{tabular}{|l|c|c|c|}
\hline \multirow{2}{*}{\multicolumn{1}{|c|}{ Landuse }} & \multicolumn{3}{|c|}{ Area (Ha) } \\
\cline { 2 - 4 } & $\mathbf{2 0 1 1}$ & $\mathbf{2 0 1 3}$ & $\mathbf{2 0 1 6}$ \\
\hline Reservoir & 8.04 & 8.04 & 3.92 \\
\hline Town forest & 160.93 & 160.93 & 157.74 \\
\hline Industrial zone & 346.29 & 385.01 & 446.80 \\
\hline Settlement & 1825.84 & 1855.94 & 2087.61 \\
\hline Open spaces & 452.14 & 214.35 & 247.35 \\
\hline
\end{tabular}

Source: Data Processing 2018

BPS Jakarta Barat, 2016 explains that the town village has the most widespread in Cengkareng is Kapuk with an area of $563 \mathrm{Ha}$, while having the most narrow is KedaungKaliangke with an area of 281 ha. The results of the identification of land use through Google image in table 4, in Cengkareng, indicate there are five land use types i.e. dam/reservoir, forest town, an industrial area, settlements, and open space. Land area industrial area from 2011 to 2016 is experience an expansion of as much as 100.51 hectares. While the settlement land area also experienced an expansion of as much as 261.77 hectares. In 2011 covering an area of 1825.84 hectares later in 2016 be 2087.61 hectares.

In general the use of land in Cengkareng be form as Settlements that is 71 per cent of the total area, then followed by an industrial area covering about 23 per cent, 9 per cent open space, town forest 5 percent, and the dam/reservoir covering an area of less than 1 percent as shown in Figure 8. Land use change in Cengkareng is very dynamic. The high population growth in the region every year cause municipalities become rapidly so dominates the land use. There are regular settlements such as housing and irregular settlements, however irregular settlements are more dominant, which later developed into the slums of areas such as the neighborhoods around the industrial area and on the banks of the river, for example, neighborhood in the Angke River. The main causes of the incidence of settlements in Angke riverbank, RawaBuaya is the failure of the Government of DKI Jakarta in the effort of providing decent housing for immigrants who have a low income [9]

Based on landuse mapping, industrial area disributed in Cengkareng Timur, Kedaung Kaliangke, and Kapok. Industrial sector is the main source of income of people living around the area of the industry. Whilet the settlement around the area of the industry are generally classified as slums as well as patterned irregular and has little open green space. Land use change each year showed no significant difference, but the settlement hasincreased quite significantly by 2016 from 1855.94 ha -2087.61 ha be as in Figure 8.

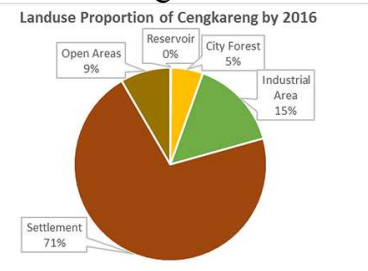

(A)

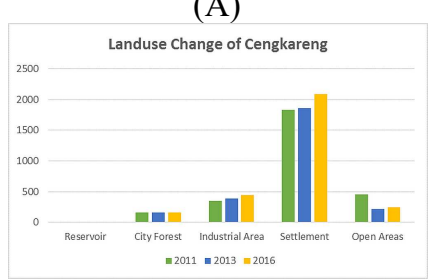

(B)

Fig 8. (A) Distribution and (B) Change of landuse in Cengkareng. Source: Data Processing 2018.

\subsection{Cakung Subdistrict}

Cakung Subdistrict is one of the subdistricts in Jakarta Timur. Cakung has a strategic location because it has many major roads and there are highways Cakung Cottage Pinan as Jakarta outer ring road and the plan up to the port of Tanjung Priok. In additionner by Cakung there is the Pulogadung industrial area as one of the oldest industrial regions in Indonesia that are located in RawaTerate and small industrial Village (PIK) in Penggilingan. So in terms of the economy, industrial 
activity in Cakung is very dominant, one of the largest industry events are located at Pulogadung industrial area (PT JIEP) which produce a variety of products that sold in the community. Jakarta Timur Mayor's Office is also located in Cakung Subdistrict, more precisely in Penggilingan.

The number of inhabitants in Cakung Sub district is the most populous in Jakarta Timur. During 2010 to 2015, the number of inhabitants in Cakung experienced fluctuations as seen in Figure 9. In 2010 the Cakung Subdistrict has a population of 408 thousand inhabitants, as much in the next year 2011, rising to become 510 thousand, but in 2013 decreased population being 480 thousand inhabitants and the number of inhabitants increased by 2015 which is 506 thousand inhabitants. Population fluctuations in Cakung is influenced by the number of births, the number of deaths and migration. The total population is high in Cakung caused by the characteristics of its territory as the seat of government and as the centre of industry in eastern part of Jakarta.

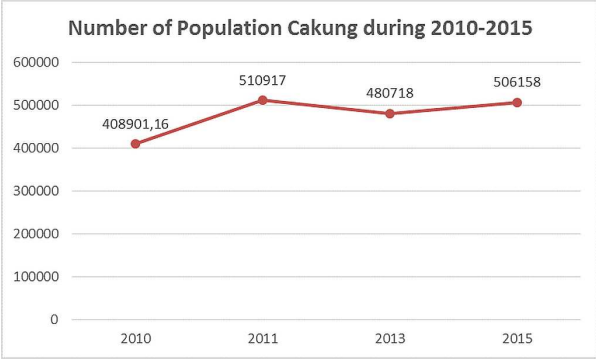

Fig 9. Population dynamic of Cakung.

Source: BPS Jakarta Timur, 2018 (Processed).

Based on population density, Cakung Subdistrict is one of the highest population density in Jakarta. During the years 2010 to 2015, the population density in Cakung experienced fluctuations in line with the population as in Figure 10. In 2011 has a density of 9628 inhabitants $/ \mathrm{km}^{2}$, the rise in 2011 be 12084 inhabitants $/ \mathrm{km}^{2}$, in 2013 decreased the population density becomes 11319 inhabitants $/ \mathrm{km}^{2}$ and it return to increase becomes 11918 inhabitants $/ \mathrm{km}^{2}$ in 2015. Population density may change due to changes in population while farm numbers are fixed so that the population density is strongly affected by population.

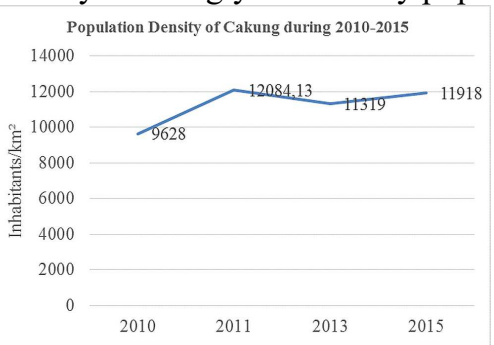

Fig 10. Population density of Cakung.

Source: BPS Jakarta Timur, 2018 (Processed).

One of the causes of population density fluctuation is migration flow. The largest number of migrants out of DKI Jakarta by 2015 comes from the Cakung Subdistrict. Migration out of Cakung Subdistrict in 2015 of 7622 people. Meanwhile, the largest number of migrants entering from outside Jakarta's by 2015 are in
Cakung Subdistrict with the amount of 8133 permanent migrants and 104 non-permanent migrants. Cakung subdistrict has an area of $42.28 \mathrm{~km}^{2}$ that is cover of 22.48 percent of Jakarta Timur $\left(188.03 \mathrm{~km}^{2}\right)$, consisting of 7 Town Village, $87 \mathrm{RW}$ and $986 \mathrm{RT}$ with a population of 523,159 inhabitants. Cakung subdistrict experiencing land use change in 2011 to 2016 . That is because by the number of development in various sectors of the district. In addition, an increasing number of residents in Cakung subdistrict which grew over the years to become one of the causes of changes in land use. Land use types in Cakung subdistrict, among others, is the dam, town forest, industrial area, open spaces, fields, ponds, extensive farmland wetlands, other public facilities, and others such as in Table 5.

In general the largest land use in district from 2011, 2013 to 2016 in the form of settlements with $54 \%$ of the total area. In 2011 to 2016 is experiencing a reduction in land use more or less amounted to 11 ha. In addition, there is also a change of land use in some locations, namely industrial area, open space, dam and others. Increased use of farm dam from 2011, 2013 to 2016 who be of 11.29 ha is one program from the local government. This is done to minimize the flooding in the area. By 2016, Jakarta Timur Municipal Government established the program to creates 30 thousand seed fish in the Pulogebang dam, this attempted by local Government aimed at improving the nutrition society.

Table 5. Landuse types in Cakung during 2011-2015.

\begin{tabular}{|l|c|c|c|}
\hline Landuse (ha) & $\mathbf{2 0 1 1}$ & $\mathbf{2 0 1 3}$ & $\mathbf{2 0 1 5}$ \\
\hline Dam/reservoir & 3,518435 & 3,795367 & 11,29054 \\
\hline Public facilities & 12,11022 & 29,561355 & 48,69883 \\
\hline Industrial areas & 1108,023 & 1079,786 & 1094,277 \\
\hline Pond & 45,31934 & 19,0548 & 12,0678 \\
\hline Rice field & 265,1931 & 305,9422 & 247,1191 \\
\hline Settlements & 2199,758 & 2198,134 & 2188,254 \\
\hline Open spaces & 437,3688 & 417,4366 & 268,339 \\
\hline Town forrest & 30,66551 & 45,0515 & 59,0515 \\
\hline
\end{tabular}

Source: Data Processing 2018

Settlement mapping results of DKI Jakarta in Figure 11 shows that the level of slums of Cakung located in low category while high until very high category dominated Cengkareng, while Penjaringan dominated by middle up to high category.

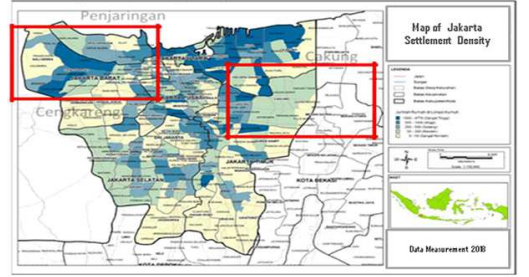

Fig. 11. Map of slum areas 2018. 


\section{Conclusion}

One of the causes of population density fluctuation is migration flow. The largest number of migrants out of DKI Jakarta by 2015 comes from the CakungSubdistrict. Migration out of CakungSubdistrict in 2015 of 7622 people. A significant change is the city forest of 30 ha by 2013 be 159.05 ha in 2016 . It experienced an increase and extension of 120 ha at various locations in CakungSubdistrict. Town forest became one of alternate media to balance the quality of the environment is declining. Town forest is very beneficial to absorb air pollutants so as to improve air quality, in addition to increasing the moisture content of the soil. Although Cakung is one of the destination of the migration workers like Cengakareng and Penjaringan.

\section{References}

1. BPS DKI Jakarta. DKI Jakarta dalam Angka Tahun 2016. Jakarta: Badan Pusat Statistik DKI Jakarta. (2016)

2. Putri, R.F., Wibirama, S., Sukamdi, Giarsih, S.R.. Sand dune conservation assessment in coastal area using alospalsarDInSAR technique. Journal of Urban and Environmental Engineering. 11 (1), pp. 9-29. DOI: 10.4090/juee.2015.v11n1.9-29. (2017)

3. Sri Sumantyo, J.T., Shimada, M., Mathieu, P.-P., Sartohadi, J., Putri, R.F. Dinsar technique for retrieving the volume of volcanic materials erupted by Merapi volcano. International Geoscience and Remote Sensing Symposium (IGARSS) 6351299, IEEE International Geoscience and Remote Sensing Symposium. (Dynamics of Earth Processes and Climate Change: Geosphere Session, TU1.14: DInSAR Applications, pp. 1302-1305. (2011)

4. Putri, R.F., Bayuaji, L., Sumantyo, J.T.S., Kuze, H. Terrasar-X DInSAR for land deformation detection in Jakarta Urban area, Indonesia. Journal of Urban and Environmental Engineering. 7 (2), pp. 195-205. (2013)

5. Putri, R.F., Wibirama, S., Alimuddin, I., Kuze, H., Sumantyo, J.T.S. Monitoring and analysis of landslide hazard using dinsar technique applied to ALOS PALSAR imagery: A case study in Kayangan catchment area, Yogyakarta, Indonesia. Journal of Urban and Environmental Engineering 7 (2), pp. 308-323. (2013)

6. Putri, R.F., Alimuddin, I., Sumantyo, J.T.S., Kuze, H. Landslide hazard detection using alospalsardinsar technique: Study case kayangan catchment area, Yogyakarta, Indonesia. Proceeding 34th Asian Conference on Remote Sensing 2013, ACRS 2013, 4, pp. 3737-3743. (2013)

7. Purnama, Setyawan, dkk. Estimasi Risiko Kerugian Ekonomi Akibat Banjir Rob Menggunakan Sistem Informasi Geografis di Kecamatan Penjaringan, Jakarta Utara. Jurnal SPATIAL Wahana Komunikasi dan Informasi Geografi, 14, 2, (2015)
8. BPS Jakarta Barat. Kecamatan Cengkareng dalam Angka Tahun 2016. Jakarta Barat: Badan Pusat Statistik Kota Administrasi Jakarta Barat. (2016)

9. Asvada, Anne. Pengendalian Pembangunan Permukiman Dibantaran Kali Angke Kelurahan Rawa Buaya Kecamatan Cengkareng Jakarta Barat. Jurnal Teknik Pwk, 2, 4 (2013) 